Vol. 6, No. 1, 2020

Bohdan Cherkes ${ }^{1}$, Iliia Lytvynchuk ${ }^{2}$

\title{
SPONTANEOUS AND REGULAR MODELS OF FORTIFIED CITIES OF UKRAINE IN THE 16TH-17TH CENTURIES
}

\author{
${ }^{1}$ Director of Institute of Architecture and Design \\ Lviv Polytechnic National University, Lviv \\ e-mail: tschers@polynet.lviv.ua \\ orcid: 0000-0001-6809-956X \\ ${ }^{2}$ PhD Student of Department of Architecture and Conservation \\ Lviv Polytechnic National University, Lviv \\ e-mail: i.lytwynczhuk@gmail.com \\ orcid: 0000-0002-4635-060X
}

Received: 14.02.2020 / Revised: 12.05.2020 / Accepted: 12.05.2020

(C) Cherkes B., Lytvynchuk I., 2020

https://doi.org/10.23939/as2020.01.001

\begin{abstract}
The Ukrainian frontier lands have introduced the principles of early-modern European urbanism which primarily included a defense component in the 16th-17th centuries. The inventory papers and studies of that time indicate that the presence of defense structures around the settlements was determined by the city status, which gave privileges and responsibilities to defend and keep both the city and castle fortifications. However, the presence of archaic ancient Kievan Rus' traditions continued in the lands of Podillia up to the 18th century, which is proved by the inventory plans taken by cartographers of the Russian Empire after the Second Partition of the Polish-Lithuanian Commonwealth.

We distinguish between the two main types of fortifications which formed the basis of urban development and influenced their urban model. The first one is called spontaneous - it was formed without any integral plan; the second type is a regular one - the location of the defense system, market square, and sacral structures was designed according to the carefully developed plan.

The basis of our research methodology is the fact that the planning structure of the historic city was invariable during the 16th-17th centuries and the works on the relics of ancient planning that have been preserved up to present (mentioned above cadastral prints). The stability of a design structure depended on the following factors: 1) slow colonization process in the border areas and, as a result, low urban growth 2) insufficient funding of the modernization of urban fortifications by the owner, possessor or the state 3) stable estate property management system which regulated the size of the plots.

This systematization indicates that the application of regular principles in the city foundation on the steppe border is an exception rather than the usual phenomenon. On the territory between rivers Dniester and Bug we identified 15 cities and fortifications having features of regular planning, and 148 - spontaneous.

Thus, the two models of urban development of the Ukrainian cities located on the steppe border in the 16th-17th centuries are analyzed. The analysis proves a close interrelation between the model of urban development and its defense system. It is defined three plans of urban development of border cities:

1. Conservation of urban planning structure of spontaneous planning due to economic stagnation or inappropriateness in the modernization of urban fortifications (Vinnytsia, Bratslav, Khmilnyk).

2. Development of a new city using the idea in cruda radice according to modern principles of fortifications of the 17th century and principles of regular city planning (Yampil, Rashkiv, Kalush).

3. Combination of old spontaneous and regular model principles of urban development in the process of modernization.
\end{abstract}


The proposed method of identification of city elements by cadastral prints can be used only in combination with a careful evaluation of information on the settlement history, and by comparing it with historical context and events, as well as with a full-scale survey of preserved relics on the area.

Key words: fortifications, regular, border, cadastral footprint, defence, Podillia.

\section{Problem statement}

The Ukrainian frontier lands have introduced the principles of early-modern European urbanism which primarily included a defense component in the 16th-17th centuries. The inventory papers and studies of that time indicate that the presence of defense structures around the settlements was determined by the city status, which gave privileges and responsibilities to defend and keep both the city and castle fortifications. However, the presence of archaic ancient Kievan Rus' traditions continued in the lands of Podillia up to the 18th century, which is proved with the inventory plans taken by cartographers of the Russian Empire after the Second Partition of the Polish-Lithuanian Commonwealth.

\section{Analysis of recent research and publications}

There is no separate category of monument or site of cultural heritage which is directly related to urban fortifications especially to the lost aboveground substance in modern Ukraine. Earthwork fortifications are essentially structures built at the intersection of several industries: urban planning, architecture, military engineering, and environmental management. The method of identifying elements of earlier planning is suggested by M. Bevz (2004), and similar principles are used by O. Rybchinskyi (2017), I. Okonchenko (2014), and R. Mohytych (1994) in their urban studies. The British scientist J. Cohen (2017) introduced the term "cadastral footprint" which directly refers to the idea of our research and allows us to identify different models of the Ukrainian cities' development in the 16th-17th centuries.

\section{Basic theory part}

Eastern Podillia was mainly characterized by the use of wood-earthwork fortifications and, as a result, nowadays, there is a small number of items preserved. We distinguish between the two main types of fortifications which formed the basis of urban development and influenced their urban model. The first one is called spontaneous - it was formed without any integral plan; the second type is a regular one - the location of the defense system, market square, and sacral structures was designed according to the carefully developed plan. The first type of fortifications followed the ancient principle of traditional construction and was not adjusted to the use of new artillery. On the steppe Ukrainian border, the nomadic tribes were the main enemy, whose military tactics had not changed since the 13th-14th centuries. They chose the well-known Ukrainian routes (such as Voloskyi, Chornyi, Kuchmanskyi) and avoided to siege the fortress cities, but mainly attacked villages or small towns. This type of fortification consisted of moats and shafts (the latter might have had a wooden frame inside) and wooden walls formed by horodnya (a local type of wooden fortification containing indoors between the towers), as well as gates and towers having rectangular or granular plan. To prevent the burning of wooden structures, the horodnyas were plastered with clay and whitewashed, although it was not always done properly which led to fires and destruction of fortifications, for example, the castle of Bratslav was burned by the troops of Khan Devlet Giray in 1551 (Mal'chenko, 2001, s. 112).

The second type consisted of modern bastions which were later transformed into bastion fortifications of European fortification schools, and after having been developed into stone fortresses, they again became wooden-earthwork construction at the end of the 17th century. Towers and wooden walls disappeared from the city fortifications: towers were convenient landmarks for targeting enemy artillery, and wooden walls were ruined because of penetration by hostile cores, and their fragments served as an additional military force. Instead, low wide earthworks with a picket fence (parapet) for close musket combat were built. It was only possible to make a hole in such a wall with the help of mines, and all roads to the city were covered by crossfire from bastions and ravines. It is easy to notice that the stone constructions in the eastern part of Podillia failed to develop, and there are only some preserved samples of stone defense structures in the cities of the bastion type 
(walls of the Vinnytsia Jesuit College, the castle of village senior in Khmelnyk, Zamoisky Castle in Sharhorod). Otherwise, the western part of Podillia had a rich number of stone castles - the castles in Rikhta, Chornokozyntsi, Panivtsi, Yarmolyntsi, Sutkivtsi, and other towns. These castles became the residences of the Polish nobility, which was firmly settled since the 15th century on the lands of West Podillia, due to the established feudal order in Poland. At that time, eastern Podillia was under Lithuanians' rule, and the urbanization process on the eastern border of the state was still at its initial level and did not fully develop because of the decline of this state in the second part of the 16th century.

The basis of our research methodology is the fact that the planning structure of the historic city was invariable during the 16th-17th centuries and the works on the relics of ancient planning that have been preserved up to present (mentioned above cadastral prints). The stability of a design structure depended on the following factors: 1) slow colonization process in the border areas and, as a result, low urban growth 2) insufficient funding of the modernization of urban fortifications by the owner, possessor or the state 3) stable estate property management system which regulated the size of the plots.

At that time, the old part of the city was not redeveloped but only changed by adding a new structure to the existing one. This was the case until the end of the period of fortified cities which is considered to be the last year of the Tatar raids (1769). Then, we can distinguish the three factors the combination of which led to the regulation of cities at the end of the 18th century: 1) real-estate system change happened after the seizure of right-bank Ukrainian lands by Russia (1792), which mostly led to the loss of property for former Polish nobility and religious institutions, and it was followed by the confiscation and redistribution of land by the Russian authorities; 2) political-economic factor means a different level of potential in concentration and management of large resources for urban reconstruction as compared with the feudal Polish Republic and the absolutist Russian Empire; 3) ideological factor is based on the ideas of Classicism borrowed from the West by Russia in the second half of the 18th century, which became the tool to implement a new imperial order in the newly acquired territories, a kind of identity marker of the Empire. The redevelopment of the historical cities of Ukraine such as Cherkasy, Kyiv, Poltava, Proskurov (Fig. 3), and others was carried out on this basis. In general, it was the case for important administrative centers of the region - county cities (Bordunova, 2012, s. 43-47).

The second stage of mass regulatory reconstruction, which included not only the cities but villages as well, occurred in Soviet times in the second half of the 20th century and was done according to the general plans which agreed with the building codes and regulations of that time. These changes were aimed at improving the functional and sanitary norms of the settlements as well as for the ideological propaganda purposes - the center of the composition of the Soviet village was the square with public buildings (Houses of Culture, village councils, monuments of Lenin, or monuments to honor the October revolution). It led to the destruction of the national identity of the Ukrainian historic city, though we should say that these master plans were rarely fully implemented.

The most important task for our analysis is to distinguish between the natural historical planning and regulatory planning and to achieve it, the two groups of map sources were studied. The first group encounters plans of right-bank Ukrainian cities, which were recorded manually by Russian topographers in the second half of the 18th century. The second group includes post-war urban and village original plans, and a prerevolutionary map with a scale of two versts (an obsolete Ukrainian unit of length equaled to 3.500 feet) at the beginning of the 20th century, which was republished by the Soviet authorities during the interwar period. As it is the large-scale map, it shows the street network of each neighborhood of a settlement. To conduct a comparative analysis, we use the existing cadastral and military topographic plans of cities of the 19th century as our extra source of information. We also need to investigate modern topo-geodetic urban plans and orthophoto plans (space surveying of Google Earth, Bing, Yandex, national geo-fund systems) to gain more information to conduct a comparative analysis.

The cities of Belz, Lutsk, Berezhany, Sudova Vyshnia are well known for their original planning structure which is identified as spontaneous. The comparative analysis shows that, in the 15th-16th centuries, all of them were characterized with the following features: 1) the market square had a spindle (triangular and elongated) shape; 2) the downtown was elliptical; 3) there were one or two rows of quarters around the market square; 4) several directions of roads led to the city gates. It is important to mention that despite the 
administrative status of the cities, their economic capacity and direct state funding, the traces of planning from the times of Princes' reign had been fully preserved for centuries and were not radically redeveloped as it was the case in the 19th-20th centuries. In the case of Podillia, such a structure would have had the voivodeship center of Bratslav and other oldest cities in the region. However, the studies of the urban development of Bratslav are complicated by the fact that the land area of the city was completely dug due to the production of saltpeter here, and the city "moved" to the other bank of the river in the 18th century. It means that the cartography of the late 18th century is not a sufficient source for further analysis of the reconstruction of the original city planning.

The city of Yampil is also an interesting example to study. It was founded at the beginning of the 17th century (the first manuscripts date to 1634 (Zurkowski, 1860. p. 151) despite the widespread belief of its foundation in the 16th century. This city was built on an empty ground - no evidence about the existence of an earlier settlement has been found. The historic city center and its market place are identified by the plans of the end of the 18th century and the year 1819; historic downtown planning has been preserved till present days. The metrological analysis shows that the Polish length measures called cords $(43.2 \mathrm{~m}$ ) were used in the planning of the city. The width of a typical quarter of the city center equals one cord and its length is 1.7 (proportions close to the "golden ration"). U. Verdum states that the city was surrounded by an earthwork and a moat (Liske, 1876, p. 151). The fortifications are considered to be rather strong as the Turks had to dig two mine chambers to blow up the shaft during the siege. Triangular formations resembling bastions are noticeable on the corners of the square city center. The average distance between them is $350 \mathrm{~m}$ (maximum firing range of guns of that time was up to $500 \mathrm{~m}$ ).

The principle of Yampol's planning is very similar to the one of Kalush (Fig. 1). It should be mentioned that Kalush was governed by starosta (local governor) which implies that it was a state administrated city; its starosta called Tomasz Zamoyskiy was the owner of Yampol, and then his son Jan became the starosta of Kalush (Lunyak, 2013). The urban development of Kalush has been recently studied by Prof. Z. Lukomska, who identified the city regular structure and bastion city fortifications on using the manuscripts of historical planning. The author found out that a new regular downtown was built in a new location next to an old irregular city which was decayed; the foundation of a new regular center dates to 1616-1630. At the same time, the city of Yampil was also approximately developed on an empty site and is likely to be a project of a single urban planner.
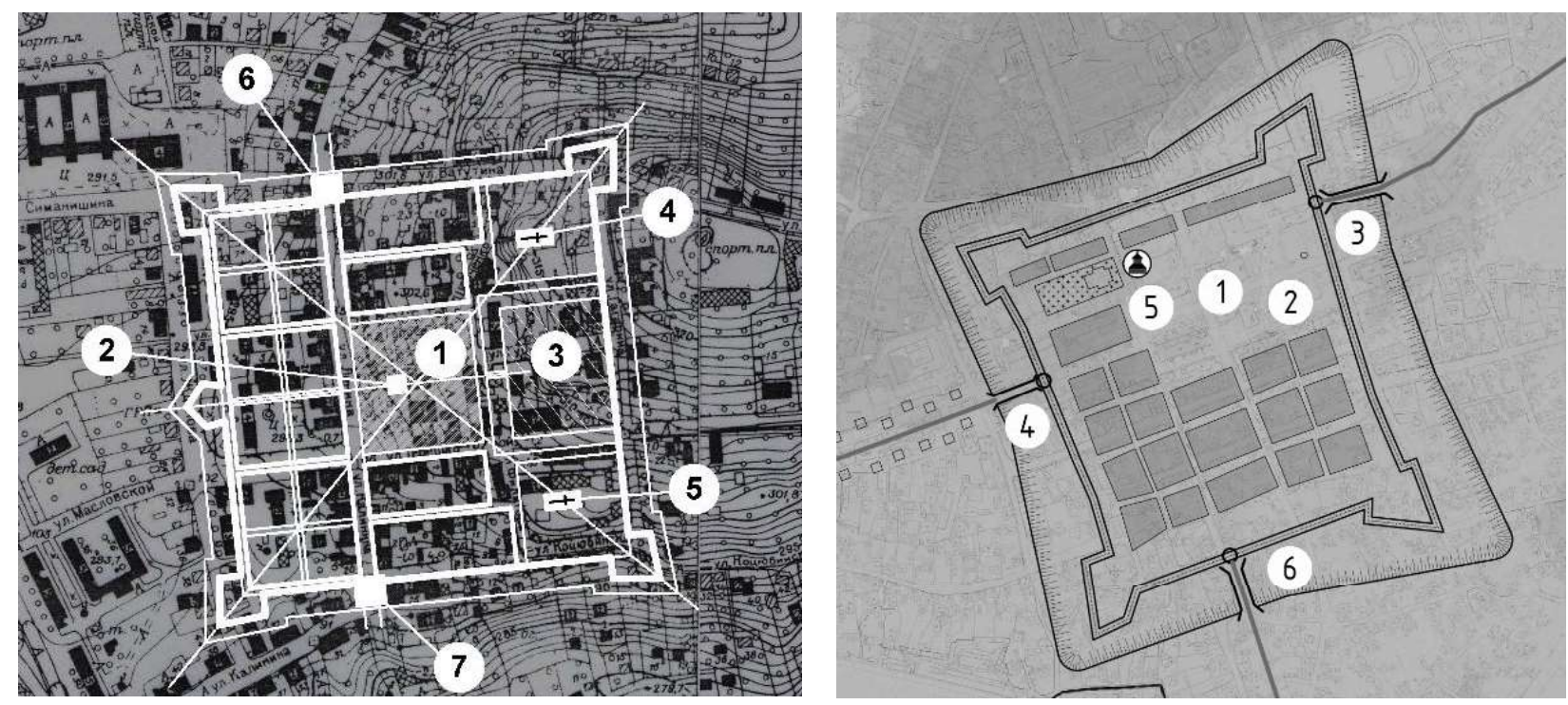

Fig. 1. On the left - Kalush defence system (by Z. Lukomska):

1 - Market Square; 2 - Town Hall; 3 - Territory of the Starosta Castle;

4 - Church of St. Valentine 5 - Church of St. Mikhail; 6 - Lviv Gates;

7 - Galitsky Gates (Lukomska \& Malyshko, 2015);

On the right - Yampol defence system (by I. Lytvynchuk):

1 - Market Square; 2 - City Well; 3 - Tomashpil Gates; 4 - Mogilev Gates;

5 - Church; 6 - Castle wicket (Lytvynchuk \& Rybchynskyy, 2019) 
At the end of the 18th century, the defensive structures of the city were transformed into a village area. It is mainly connected with a shift in a military doctrine - battles moved to the field location, and to win a fortress of the city meant little for the fighters. In this regard, it was not reasonable to spend a lot of funding to maintain urban fortifications. The territory of the defensive city structures was rented out to arrange public spaces boulevards, avenues, or for the construction works, or to give to the religious organizations into possession. The comparative analysis of cadastral maps of Brody and Bogorodchany of the middle of the 19th century proves that the residential parcels of land are connected with the shafts and moats on one side, generally in a perpendicular way to their rectangular section. The streets are thus formed along the earth shaft and/or outer edge of the moat. It allows us to consider both the street network and the subdivision of neighborhoods to identify defense relics in cities.

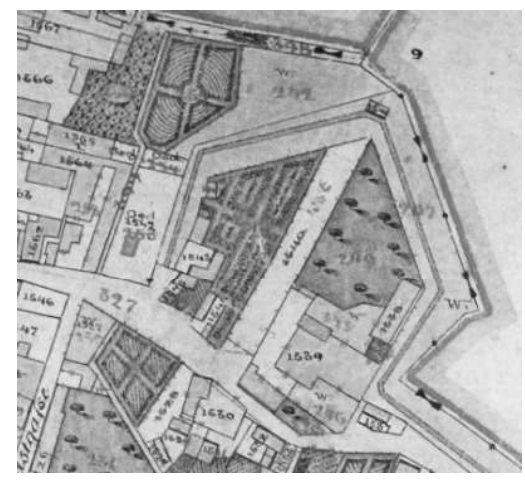

a

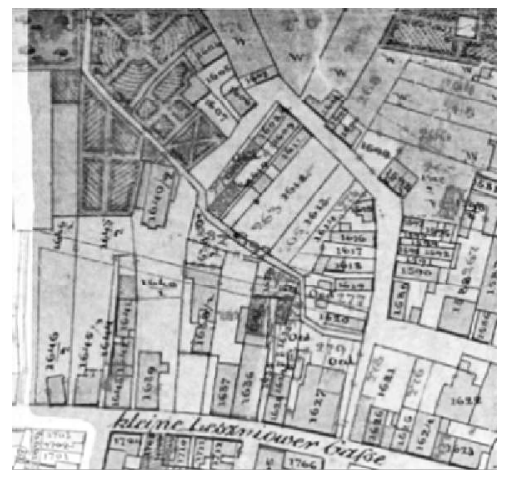

b

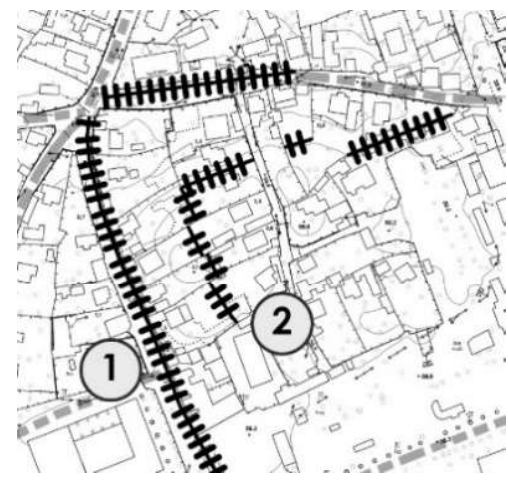

Fig. 2. Preserved bastion with a park in Brody, middle 19th century (a), Partition of a demolished bastion for further construction works (Gesher Galicia, 1844) (b), Identified partition of the city fortifications in Yampil (c)

\section{Results and discussions}

Having analyzed sources of documentary information and full-scale studies of some cities, we developed a map (Fig. 3) which shows the cities and their fortifications present in the 17th century. In Rashkov (ESBE, 1899, p. 396), the two undeveloped platforms of earthwork bastions are well preserved, and the acts of that time prove that a well-known Italian architect and fortifier Andrea Del Aqua was invited to join the urban fortifications project. The new Konetspil (VRU, 2019a) was laid down by Boplan, of which he himself wrote in his "Essays on Ukraine ...". On-site examinations reveal the remains of a small bastion with coordinates $48.137388,30.096169$. The city bastion fortifications and the castle are marked on the plan of the city of Chyhyryn in 1677. In Kisnytsa (VRU, 2019b), a Swedish Ambassador Jakob Hilderbrand (Olyançin, 1937, pp. 51-52) saw "a well-made sconce he had never met throughout Ukraine," and its remains were also noticed by the Swiss architect J. Muntz (Budzińska, 1982, pp. 283-284) in 1781. According to him, the abandoned fortification could even then be defensible and protect the crossing of the Dniester River if it had been reconstructed. Studying the route of Hilderbrant from Kisnytsa to Chyhyrin and from Chyhyrin to Kamyanets via Bratslav, we can assume that the fortifications in the cities of his route did not meet the requirements of that time. Further along the Dniester river, the most recent fortifications are found in cities of Yampil, Mohilev, Zhvanka (bypassed by Hilderbrand), and Trenches of the Holy Trinity which were founded later. The fortifications of the cities of Medzhybozh, Bar, Bila Tserkva are marked on the maps of the 17th-18th centuries. In the cities of Sharhorod, Tomashpol, and Krasnov (which were owned by the Zamoyski family), modern fortifications similar to the Rashkivskyi ones are assumed to be used. In Novograd (Verkhivka village, Vinnytsia region (ESBE, 1892, s. 79), the remnants of the small five-angled fortress developed by the architect Boplan are preserved. An interesting object of castle fortification is a so-called Rakoczi Castle which according to archaeological studies dates back to the first half of the 16th century, but according to its shaft outline is similar to the tenaille fortifications, which became known only in the 18th century. Instead, historical papers, cartography (AGAD 1772), and archaeological investigations point out the existence of a stone tower system which was also the feature of the 16th century. 
This systematization indicates that the application of regular principles in the city foundation on the steppe border is an exception rather than the usual phenomenon: there are 15 cities and fortifications having features of regular planning, and 148 of spontaneous. These numbers do not include cities with the castles of regular planning, though their amount was significantly higher on the border area, and the presence of which in cities did not affect the model of their development.

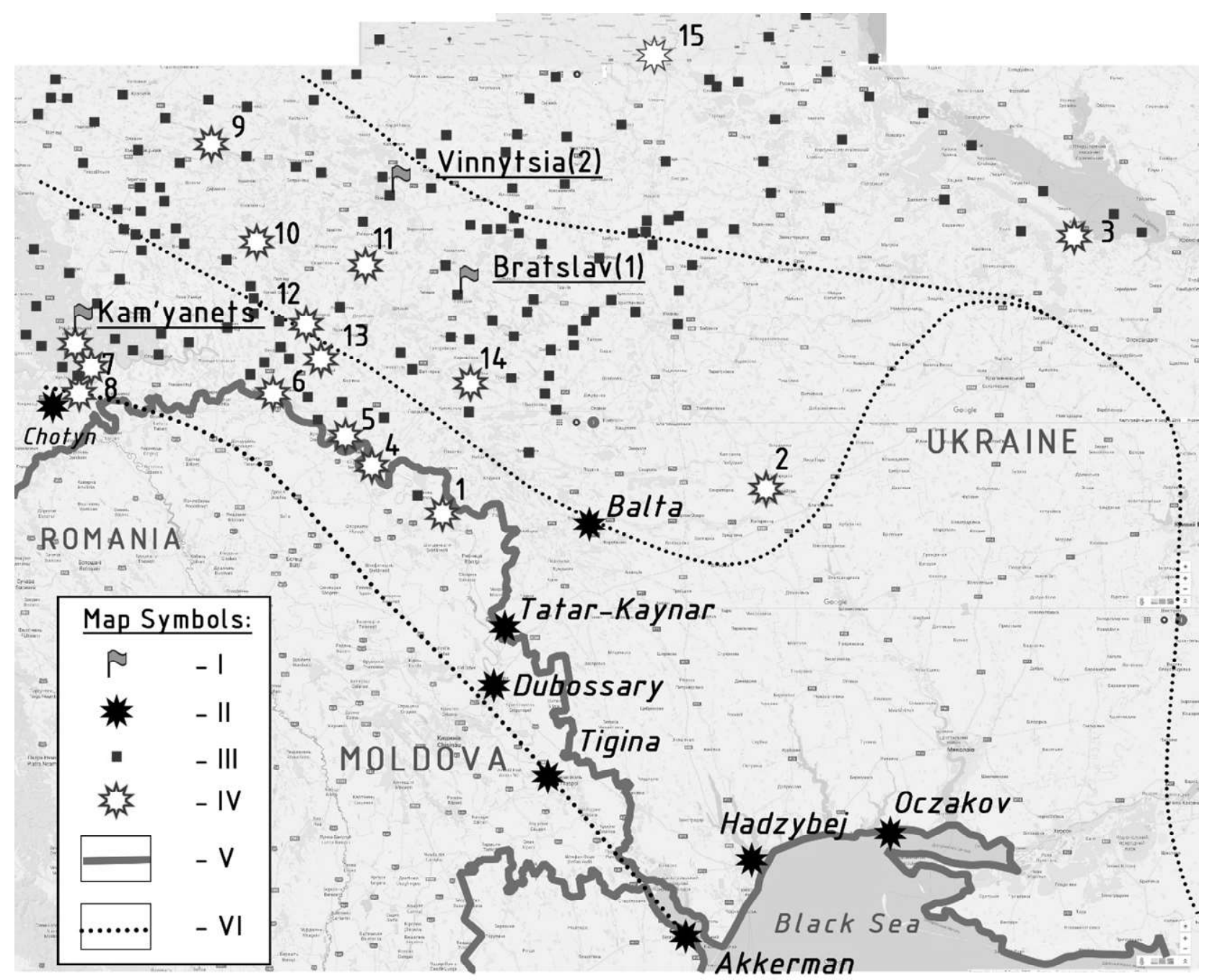

Fig. 3. Cities with proven or hypothetical presence of regular fortifications in the 17th century:

1 - Rashkiv (field surveys by I. Lytvynchuk); 2 - Novyi Konetspil; 3 - Chyhyryn; 4 - Velyka Kisnytsia; 5 - Yampil; 6 - Mohylev; 7 - Trenches of the Holy Trinity; 8 - Zhvanets; 9 - Medzhibizh; 10 - Bar; 11 - Krasne; 12 - Sharhorod; 13 - Tomashpol; 14 - Novohrad; 15 - Bila Tserkva.

Map symbols: I) the capitals of voivodships, II) the enemy's fortress, III) the fortress towns of the Commonwealth (archaic type), IV) modern type, V) state border of Ukraine, VI) the ways of penetration of the Tatars (developed by I. Lytvynchuk, 2019)

Using the method above, we are going to investigate the city of Sharhorod, Vinnytsia region (Fig. 4). At the end of the 16th century, Jan Zamoiskyi, the Chancellor of the Commonwealth, bought the city (known as Kniazha Luka) and began to develop it as his main residence in Podillia. Jan Zamojskiis well known for building a castle to defend the Tatar invasions, but his input into the development of the city fortification system is little studied. The search for the remains of the Renaissance planning of the city did not show any results. However, even in the modern shape of the market square, it is clearly read its archaic elongated form with neighborhoods of different lengths and the outlines of the city center. The side part of the city center, which is mostly adjacent to the field area, with its hypothetical original fortification is destroyed by the territorial extension of the city along the road to the north, relics of the old city boundaries run along the street of Heroes of Maidan and Grel street. There are some streets going from the city gates and leading to the direction of 
Khmilnyk and Vinnytsia. The location of St. Florian's Church which was built by Zamoyskyi outside the Old City (Khniazha Luka) boundaries tells us that there was not any available space found in the neighborhoods of the market square and the owner had to move the construction site to the suburban area. The most dangerous area was the outside part of the city in the north. It had to be protected by using the modern strategy of defense. The most reasonable solution would be to place a crownwork similar to the one developed in New Castle in KamianetsPodilskyi, or in Pomoriany (Rybchynskyy, 2017, p. 392, Fig. D.5), which would block the cape mouth from the invasion. According to the studies by Ulrich von Werdum (Liske, 1876, p. 148), the city was surrounded by a shaft with a moat. The parcellation along the main street, which leads in the direction of Khmilnyk, is made in the form of a "fir tree". It indicates a breakdown that is parallel to the sides of the bastion crownwork or curtain work. They are also placed near the church of St. Florian as it is thought that the church was built at the end of the present construction and the new city boundary had to be protected immediately. It is not known whether the defense shaft of New City was adjacent to the Old City. Having the natural terrain and inaccessibility of the city on three sides, it would be enough to cover the mouth of the cape with a shaft to organize an effective city defense. However, the New City construction has mostly a plan of regular neighborhoods, but it has also preserved the relic of the old spontaneous city with its road crossing near the Old City gates.

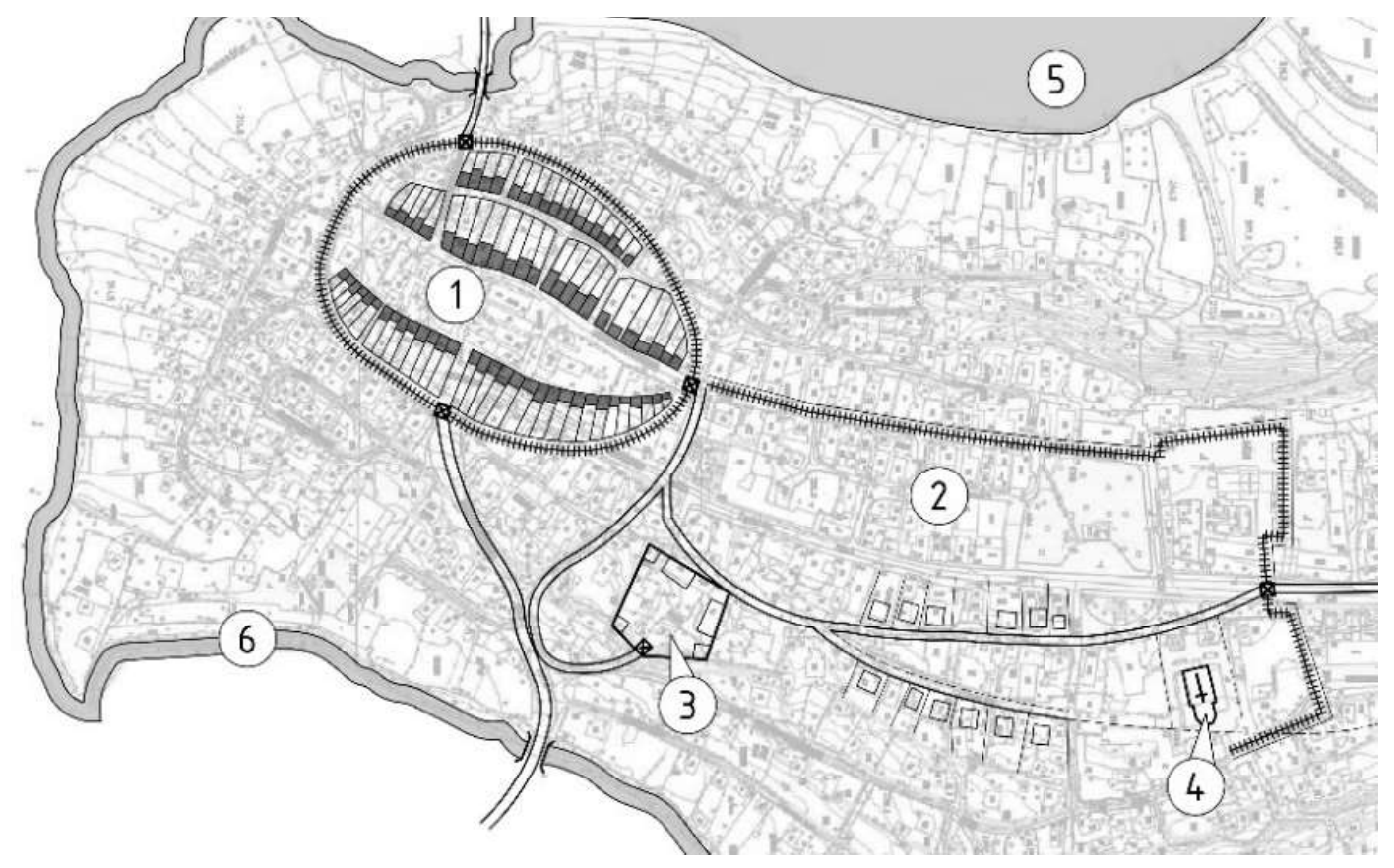

Fig. 4. The coexistence of the Old City in Sharhorod (Kniazha Luka settlement) and the New City (built by Jan Zamoyskyi and his son Tomasz):

1 - Old City with market square, 16th century; 2 - New City, first part of the 17th century; 3 - ZamojskiCastle, 4 - St. Florian's Church

5 - city pond; 6 - Murafa river

(developed by I. Litvinchuk)

\section{Conclusions}

Thus, the two models of urban development of the Ukrainian cities located on the steppe border in the $16^{\text {th }}-17$ th centuries are analyzed. The analysis proves a close interrelation between the model of urban development and its defense system. It is defined three plans of urban development of border cities:

1. Conservation of urban planning structure of spontaneous planning due to economic stagnation or inappropriateness in the modernization of urban fortifications (Vinnytsia, Bratslav, Khmilnyk).

2. Development of a new city using the idea in cruda radice according to modern principles of fortifications of the 17th century and principles of regular city planning (Yampil, Rashkiv, Kalush).

3. Combination of old spontaneous and regular model principles of urban development in the process of modernization. 
The proposed method of identification of city elements by cadastral prints can be used only in combination with a careful evaluation of information on the settlement history, and by comparing it with historical context and events, as well as with a full-scale survey of preserved relics on the area

\section{References}

AYUZR, 1890. Archive of Southwestern Russia, issued by the Provisional Commission for the Analysis of Ancient Acts, established under the Governor-General of Kiev, Podolsk and Volyn, part 7 t. 2.

Bevz, M., 2004, Methods of Identification and Verification of Multiple Elements of the Planning and Spatial System of a Historic City (on the Belz City Example). Bulletin of the National University "Lviv Polytechnic". Series: Architecture, 505, c. 350-60.

Boplan, H., 1990, Description of Ukraine, several provinces of the Kingdom of Poland, extending from the borders of Muscovy to the borders of Transylvania, together with their customs, lifestyles and wars. Translated from the French by J. Kravets and P. Borysyuk. Kyyiv: Nauk. dumka

Bordunova, Y. R., 2012. Feeding book of Russian urban planning. Territory and Planning, 4, s. 43-47.

ÉSBE, 1892. Verkhovka In: Brockhaus and Efron Encyclopedic Dictionary, t. 6, s. 79.

ÉSBE, 1899. Rashkov. In: Encyclopedic Dictionary of Brockhaus and Efron, t. 26, s. 396.

Havrylenko, F.. 2018. Khmelnitsky (Khmelnitsky): urban fortifications of Ploskirov [online] Available at: $<$ https://forum.zamki-kreposti.com.ua/topic/1768-khmel'nytskyy-khmel'nyts'kyy-horodskye-ukreplenyya-ploskyrova/> [Accessed 10 April 2019]

Hul'dman, V., 1901. Monuments of old Podolia. Kamenets-Podol'skyy: Typohrafyya Podol'skoho hubernskoho pravlenyya, s. 153.

Ihnat"yev, I. ta Pohorilets', O., 2012, Aerial photography - as a method of finding and exploring the remains of the medieval fortress "Rakocci Castle". New Studies of Cossack Age Monuments in Ukraine: Coll. of sciences, 21, ch. 1, s. $214-218$.

Kaplins'ka, M., 2014, Long Markets in Historic Cities of East Galicia. Bulletin of Lviv Polytechnic National University. Architecture Series, 757, s. 302-309.

Kopylov, S., ta Zadorozhnyuk, A. 2011. Descriptions of Podilskyi province at the end of XVIII - beginning of XIX century. Kam"yanets'-Podil's'kyy: Aksioma, s. 98.

Lukoms'ka, Z. ta Malyshko, O. 2015, Town-planning heritage of Kalush from the XV-XVIII centuries. Contemporary Issues of Research, Restoration and Preservation of Cultural Heritage: Coll. of sciences. of Art Studies, Architecture and Cultural Studies, 11, s. 183-188.

Lukoms'ka, Z., 2004. The City of Ivano-Frankivsk - History and Modernity. Bulletin of the National University "Lviv Polytechnic”. Series: Architecture, 505, s. 198.

Lunyak, Ye., 2013. Cossack Ukraine of the 16th - 18th centuries [online] Available at: < https://www.myslenedrevo. com.ua/uk/Sci/HistSources/CossackUkraineFrance/Magdeleine.html > [Accessed 10 April 2019]

Lypa, K., 2007. Under the protection of walls. Kyyiv: Nash chas, s. 44.

Lytvynchuk, I ta Rybchyns'kyy, O. 2019. A comprehensive study of the urbanistic genesis of the fortified city of Yampol, Vinnytsia region. Current issues in research, conservation and restoration of historic fortification, 11, s. 120-51

Mal'chenko, O., 2001. Fortified settlements of the Bratslav, Kyiv and Podilsky provinces of the 15th-the middle of the 17th centuries. Kyyiv: Natsional'na akademiya nauk Ukrayiny, Instytut ukrayins'koyi arkheohrafiyi ta dzhereloznavstva im. M. S. Hrushevs'koho.

Matviyishyn, Ya., 2003, Picturesque plans of three Ukrainian castle-fortresses from the XVII century. (Bar, Medjimboja, Chyhyryn) in the Diplomatic Archives of the Ministry of Foreign Affairs of France. Historical Cartography of Ukraine, p. 195-200.

Mohytych, R., 1994 Bibrka. (princely days in the planning structure of Western Ukrainian cities). Bulletin of UkrZahidProjectRestoration, 2, s. 3-9.

Okonchenko, I., ta Okonchenko, O., 2014 Chronology of the genesis of the fortifications of Zhovkva. Zhovkva through the ages, 3 , c. $104-18$

Olyanchyn, D., 1937, Description of the Swedish Ambassador's voyage to Ukraine 1656-1657. Notes of the Scientific Society. Shevchenko, t. 154, s. 51-52.

Rybchyns'kyy, O., 2017. Formation and revitalization of the middle ground of historical cities of Ukraine. Doctor of Architecture. L'viv, c. 97-8

Rychkov, P., 1992. Sources of the Russian State Military-Historical Archive to the History of Urban Planning in RightBank Ukraine. Archives of Ukraine, 5/6, s. 52-61

Rychkov, P., 1996. Market Square. Monuments of Ukraine: History and Culture, 2 s. 26-31.

Setsynskyy, E., ed., 1901. Proceedings of the Podolsk Diocesan Historical and Statistical Committee, 9. KamenetsPodol'skyy: Typohrafyya S. P. Kyrzhatskoho, Nykolaevskaya ploshchad', d. No. 5.

Sitsins'kyy, Yu., 2001. Archaeological map of Podolsk province: facsimile reprint. Ed. Bazhenov, O., ta Vynokur., I. Kam'yanets'-Podil's'kyy: Tsentr Podillyeznavstva.

Ters'kyy, S., 2006. Lucessk of the $X-X V$ centuries. Lviv: Publishing House of the National University "Lviv Polytechnic, s. 75

Upravlinnya mistobuduvannya ta arkhitektury Vynnyts'koyi oblasnoyi derzhavnoyi administratsi, 1987. Yampol of Vinnytsia Region. Master plan and first stage of construction, Inv. No. 6586. 


\author{
Богдан Черкес ${ }^{1}$, Ілля Литвинчук ${ }^{2}$ \\ ${ }^{1}$ Директор Інституту архітектури та дизайну, \\ Національний університет “Львівська політехніка", Львів, \\ e-mail: tschers@polynet.lviv.ua \\ orcid: 0000-0001-6809-956X \\ ${ }^{2}$ Аспірант кафедри архітектури та реставраиії, \\ Науіональний університет “Львівська політехніка", Львів, \\ e-mail: i.lytwynczhuk@gmail.com \\ orcid: 0000-0002-4635-060X

\section{СПОНТАННІ ТА РЕГУЛЯРНІ МОДЕЛІ УФОРТИФІКОВАНИХ МІСТ УКРАЇНИ У ХVI-XVII ст.}

\begin{abstract}
Анотація. На украйнських прикордонних землях були запроваджені принципи ранньомодерного європейського урбанізму, який, насамперед, включав оборонний компонент у XVI-XVII століттях. Інвентарні документи та дослідження того часу свідчать про те, що наявність оборонних споруд навколо населених пунктів визначалася статусом міста, що дало привілеї та обов'язки захищати та зберігати укріплення міста та замку. Однак присутність архайчних давньоруських традиџій продовжувался на землях Поділля аж до 18 століття, що підтверджується інвентарними планами, зробленими картографами Російської імперії після Другого поділу Речі Посполитої.

Ми розрізнясмо два основні типи укріплень, які лягли в основу містобудування та вплинули на його міську модель. Перший ми називаємо стихійним - він формувався без будь-якого иілісного плану; другий тип - регулярним - розташування системи оборони, ринкової площі та сакральних споруд було розроблено відповідно до попередньо ретельно розробленого плану.

Методика авторів базується на тому факті, що планувальна структура історичного міста була незмінною протягом XVI-XVII століть, а роботи над реликтами автентичного планування збереглися до наших днів (згадані вище “кадастрові відбитки”). Стабільність планувальної структури залежала від таких факторів: 1) повільний процесс колонізачії в прикордонних районах $і$, як наслідок, низький приріст міст, 2) недостатнє фінансування модернізачії міських укріплень власником, власником або державою, 3) стабільна система управління майном нерухомості, яка регулювала розміри земельних ділянок.

Ця систематизачія вказує на те, що застосування регулярних принципів у фундаменті міста на кордоні степу $\epsilon$ винятком, а не звичним явищем. На території між річками Дністра та Бугом ми виявили 15 міст та укріплень, що мають особливості регулярного планування, та 148 - стихійні.
\end{abstract}

Ключові слова: укріплення, регулярні приниини, кордон, кадастрові відбитки, оборона, Поділля. 